\title{
THE ANTIBODY RESPONSES IN MAN TO INFECTION WITH DIFFERENT SEROTYPES OF GROUP-A STREPTOCOCCI
}

\author{
Jean P. Widdowson, W. R. Maxted, Clare M. Notley and \\ ALISON M. PINNEY \\ Cross-Infection Reference Laboratory, Central Public Health Laboratory, \\ Colindale Avenue, London, NW9 $5 H T$
}

AFTER infection with a group-A streptococcus, antibodies to a wide variety of extracellular and somatic antigens can be detected in the patient's serum. One of the factors that may influence the magnitude of these responses is the serotype of the infecting strain. It is well established that patients with streptococcal pyoderma have considerably lower titres of anti-streptolysin O (ASO) than do patients with streptococcal sore throat, but that titres of anti-deoxyribonuclease B (anti-DNAase B) are often very high in cases of skin infection (Anthony, Perlman and Wannamaker, 1967; Dillon and Reeves, 1969). It is not known to what extent the site of infection is responsible for these differences, but the serotypes that cause pyoderma are in general quite different from those that commonly cause disease of the respiratory tract (see Wannamaker, 1970).

Antibody against $M$ protein confers type-specific protection against reinfection with streptococci of the same serotype, and Denny, Perry and Wannamaker (1957) and Siegal, Johnson and Stollerman (1961) found that at least $70 \%$ of patients had type-specific antibody to the infecting strain after recovery from streptococcal sore throat. However, the outbreaks that these workers investigated were all caused by $M$ types that did not produce opacity factor (OF), i.e., " OF-negative M-types" (Maxted and Widdowson, 1972). Information on the antibody response in man to infection with OF-positive serotypes is lacking, but vaccines of these types are generally poorly antigenic in rabbits (Gooder, 1961; Top and Wannamaker, 1968; Widdowson, Maxted and Grant, 1970).

We have shown (Widdowson, Maxted and Pinney, 1971a) that titres of antibody against streptococcal M-associated protein (MAP) are almost invariably high in patients with rheumatic fever, but much less often raised in patients with acute streptococcal glomerulonephritis and in sporadic cases of sore throat. Later, however, we investigated an outbreak of rheumatic fever due to M-type 5 in which a considerable proportion of the patients with uncomplicated sore throat also developed high titres of anti-MAP (Widdowson et al., 1974). We have therefore studied the antibody responses of patients in a number of outbreaks due to known streptococcal types; the sera were examined for ASO, anti-DNAase B, anti-MAP, and M antibody to the supposed infecting serotype. We also examined the sera of several other groups of patients suffering from the non-suppurative sequelae of streptococcal infection of the throat or of the skin, and the sera of groups of supposedly normal persons. 


\section{MATERIALS AND METHODS}

\section{The streptococcal outbreaks}

We examined cultures and sera from six outbreaks of streptococcal upper-respiratory tract infection in four residential institutions in Britain (see table 1 ). Outbreaks nos. 3 and 4 were in schools and nos. 1, 2, 5 and 6 were in two other residential establishments for adolescents. In one outbreak (no. 1) three different serotypes, and in another (no. 4) two different serotypes were causing clinical infection at about the same time. Thus it could be said that there were nine separate incidents of throat infection: nos. 1A, 3 and 6 due to M-type 5; nos. $1 \mathrm{~B}$ and 5 due to $M$-type 18; no. 4A to M-type 12; no. 4B to M-type 22; and no. 1C to M-type 58. Six cases of rheumatic fever occurred in outbreak 1 and there was evidence that at least four of these were due to M-type 5 (Widdowson et al., 1974); there were also two cases of rheumatic fever at the time of the type-18 outbreak (no. 5) and one case at the time of another type-5 outbreak (no. 6) that occurred one year later in the same institution. The size of the outbreaks ranged from about ten clinical cases of sore throat in outbreak 3 to about 450 in outbreak 1.

Outbreak 7 was of streptococcal impetigo in Birmingham, Alabama, USA and was of undefined size. Material was received from twelve patients of Dr H. C. Dillon, all of whom were clinically infected and four of whom had acute glomerulonephritis. The causative organism was of M-type 2 with the T-agglutination pattern 8/25/Imp 19-the " Alabama 2 " strain (Dillon, Reeves and Maxted, 1968). The 20 patients of Drs T. Poon-King, I. Mohammed and R. Cox, investigated in incidents 8 and 9 were all suffering from pyoderma and acute glomerulonephritis. The outbreaks of pyoderma in Trinidad due to M-type 57 (no. 8) and M-type 60 (no. 9) were of undefined size, but involved 540 patients with nephritis (Potter et al., 1971).

\section{Streptococci}

Representative samples of group-A streptococci isolated in the residential institutions at or soon after the peak of the epidemics were received for typing (table I). A purely clinical diagnosis of streptococcal tonsillitis is often not easy to make (Kaplan et al., 1971) and it was therefore difficult to be sure which of the cultures had come from clinically infected persons. In the outbreaks of skin infection only bacteriologically confirmed cases were included. 'The streptococci were typed by T-agglutination (Griffith, 1934) and Mprecipitation methods (Swift, Wilson and Lancefield, 1943). Typing sera were prepared by the Streptococcus Reference Laboratory, Colindale.

\section{Sera}

1. From the outbreaks of upper-respiratory-tract infection. Sera were collected from samples of the population in the residential institutions, usually 4-6 weeks after the peak of each outbreak. Not all of the sera came from patients thought to have been clinically infected or who had been investigated bacteriologically at the time of the outbreak. We therefore selected for analysis groups of sera from patients who had serological evidence of recent infection and used them in the following ways to study the type-specific antibody response.

Method A. We selected all sera collected 4-6 weeks after an outbreak, in which the ASO titre was $\geqslant 200$ units per $\mathrm{ml}$ or the anti-DNAase B titre was $\geqslant 250$ units per $\mathrm{ml}$ or both. An index of the type-specific antibody response for each serotype was then obtained by applying the formula $\left(\begin{array}{l}n \\ r\end{array} \frac{t}{T}\right)$, where $n=$ the number of sera with type-specific antibody, $r=$ the number of sera with elevated ASO or anti-DNAase B titres or both, $t=$ the number of swabs yielding the given type of streptococcus and $T=$ the total number of swabs yielding group-A streptococci. This value is multiplied by 100 for convenience to give a precentage value. 


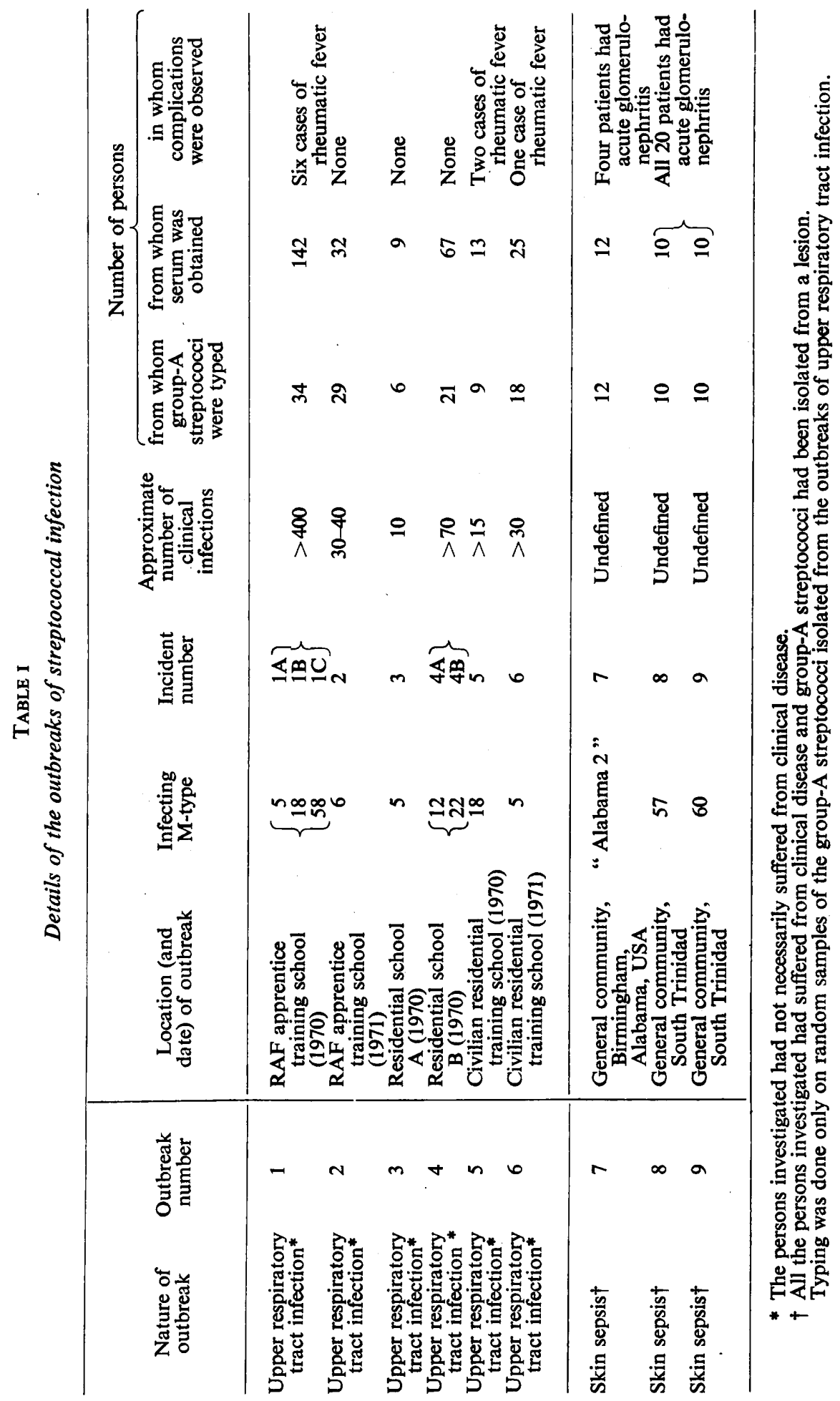


Method B. For sera collected 4-6 weeks after the isolation of the relevant type of streptococcus from the same patient, the percentage type-specific antibody response for each incident was calculated as (number of sera with type-specific antibody/number of sera from patients infected with the type) $\times 100$.

Other antibody responses (ASO, anti-DNAase B and anti-MAP) that could easily be measured quantitatively, and were not type-specific, were compared by plotting cumulative percentage values for the antibody titres of selected groups of sera from the various outbreaks; $50 \%$ values, i.e., the titre exceeded by $50 \%$ of the sera in a group, were estimated from the cumulative percentage plots.

2. From outbreaks of impetigo. On average, three serial bleedings were obtained from each patient extending over a period of several months after isolation of the strain. Many of these patients were also suffering from acute nephritis (see table I) and in these cases the first serum was collected as soon as possible after the onset of the disease. The antibody responses in these sera were studied by the same methods as those used for our studies of throat infection.

3. Sera from rheumatic-fever patients. Serum samples were collected from patients with rheumatic fever as soon as possible after the onset of disease and in some cases again a few weeks later. These sera consisted of: $(a)$ single sera collected from 47 children with acute rheumatic fever and carditis from the Pyramids Hospital, Rheumatic Heart Disease Centre, Cairo, Egypt, by Dr W. El Razaz (El Razaz, Widdowson and Maxted, unpublished); (b) single sera from 14 patients of various ages from British hospitals together with sera from the six rheumatic fever patients in outbreak 1 (Widdowson et al., 1974) and from the three rheumatic fever patients in outbreaks 5 and 6 (see table I); (c) sera (usually three serial bleedings taken over a period of 3 months) obtained from 18 patients with rheumatic fever in Trinidad by Drs T. Poon-King and E. V. Potter.

4. Sera from patients with acute glomerulonephritis. Sera were obtianed from the following groups of patients as soon as possible after the onset of disease: (a) 13 patients from British hospitals with acute nephritis after throat infection; $(b)$ five patients with acute nephritis after throat infection with M-type 2, submitted by Dr B. Anthony, Harbor Hospital, Los Angeles, California, USA (Anthony et al., 1974); (c) five patients with acute nephritis from an approved school in Britain where several other patients had had skin infections due to M-type 58; $(d)$ seven patients with acute nephritis after skin infection with unknown serotypes from Trinidad; $(e) 10$ patients from Trinidad with acute nephritis after skin infection with type 57 (incident 8-table $) ;(f) 10$ patients from Trinidad with acute nephritis after skin infection with type 60 (incident 9-table 1); $(g)$ four patients in incident 7 who developed nephritis after infection with M-type 2, T-type 8/25/Imp 19 (Dillon et al., 1968); (h) 13 patients with nephritis after skin infection from Zaria, Nigeria (Whittle et al., 1973).

5. Sera from normal persons consisted of a group of 122 single sera from British adult laboratory workers, 50 sera from normal Cairo schoolchildren and 12 sera from normal children from Zaria, Nigeria.

In the case of sera from patients with glomerulonephritis or rheumatic fever and from normal persons, the ASO, anti-DNAase B and anti-MAP titres were studied by estimating $50 \%$ values for all of the sera in each group.

\section{Antibody tests}

Anti-streptolysin $O(A S O)$ tests were performed by the spectrophotometric method of Gooder and Williams (1961).

Anti-deoxyribonuclease B (anti-DNAase B) tests were done by the micro-method of Nelson, Ayoub and Wannamaker (1968).

Indirect bactericidal tests for $\mathbf{M}$ antibody were performed as described by Maxted, Widdowson and Fraser (1973). Sera from the various outbreaks were tested against the strain or strains responsible for the outbreak. A heterologous type was included in each test as a control. 
Tests for antibody to $M$-associated protein $(M A P)$ were done by a complement-fixation test as described by Widdowson et al., (1971a).

\section{RESULTS}

The influence of serotype on the type-specific antibody response

It was possible to calculate the percentage of patients with a type-specific antibody response by both methods $A$ and $B$ for five of the incidents (1A, 2, 3, 4A and $4 \mathrm{~B}$ ) and the results are in reasonable agreement (table II). There was,

TABLE II

Type-specific antibody response in man to infection with different serotypes of group- $A$ streptococci

\begin{tabular}{|c|c|c|c|c|c|}
\hline \multirow{2}{*}{$\begin{array}{l}\text { Incident } \\
\text { number }\end{array}$} & \multirow{2}{*}{$\begin{array}{c}\text { Infecting } \\
\text { M-type }\end{array}$} & \multirow[t]{2}{*}{$\begin{array}{l}\text { Site of } \\
\text { infection }\end{array}$} & \multirow{2}{*}{$\begin{array}{l}\text { Serum-opacity } \\
\text { reaction of } \\
\text { the infecting type }\end{array}$} & \multicolumn{2}{|c|}{$\begin{array}{c}\text { Type-specific } \\
\text { antibody response } \\
\text { (and number of sera examined) }\end{array}$} \\
\hline & & & & Method $\mathrm{A}^{*}$ & Method $\mathrm{B}^{*}$ \\
\hline $\begin{array}{l}1 \mathrm{~A} \\
1 \mathrm{~B} \\
2 \\
3 \\
4 \mathrm{~A} \\
5 \\
6\end{array}$ & $\begin{array}{r}5 \\
18 \\
6 \\
5 \\
12 \\
18 \\
5\end{array}$ & Throat & Negative & $\begin{array}{r}64(92) \\
86(92) \\
67(24) \\
71(7) \\
127(61) \\
112(8) \\
95(9)\end{array}$ & $\begin{array}{l}71(17) \\
\ldots 7(0) \\
67(24) \\
100(6) \\
90(10) \\
\ldots \quad(0) \\
\ldots \quad(0)\end{array}$ \\
\hline $\begin{array}{l}4 \mathrm{~B} \\
1 \mathrm{C}\end{array}$ & $\begin{array}{l}22 \\
58\end{array}$ & Throat & \} Positive & $\begin{array}{l}34(61) \\
25(92)\end{array}$ & $\begin{array}{l}36(11) \\
\ldots \quad(0)\end{array}$ \\
\hline 8 & 57 & Skin & Negative & $20(10)$ & $20(10)$ \\
\hline $\begin{array}{l}7 \\
9\end{array}$ & “ $\underset{60}{\text { Alabama }} 2 "$ & \} Skin & \} Positive \{ & $\begin{array}{r}33(12) \\
0(10)\end{array}$ & $\begin{array}{r}33(12) \\
0(10)\end{array}$ \\
\hline
\end{tabular}

* See text for methods of calculation.

however, a striking difference between the antigenicity of the $M$ proteins of OF-positive and OF-negative serotypes in infections of the upper respiratory tract. The percentage response to the OF-negative serotypes 5, 6, 12 and 18 was at least 64 compared with $25-35 \%$ for the OF-positive serotypes 22 and 58 . The type-specific antibody response to infection of the skin with either OFpositive serotypes ("Alabama 2" and M-type 60) or the OF-negative serotype (M-type 57) was very poor and varied from $0-33 \%$.

No attempt was made to measure the titre of type-specific antibody in the sera, but in general a bactericidal effect was much more clearly demonstrable in the bactericidal test with sera from patients who had been infected with OFnegative serotypes. Antibody to the OF-negative serotypes was easily detectable in tests with a large inoculum of bacteria ( $>200$ viable units per tube). The results with OF-positive serotypes were less clear-cut, and even with positive sera it was often difficult to demonstrate a reproducible killing effect 
even against small inocula (10-20 viable units per tube). Therefore, the difference between the antigenicity of the OF-positive and OF-negative serotypes is probably even greater than the quantitative data in table II would indicate.

Production of antibody to other streptococcal antigens; streptolysin $O$, $D N A a s e \quad B$ and $M$-associated protein

In studying the responses to streptolysin O, DNAase B and MAP with respect to the serotype of the infecting strain, evidence had to be sought that the

TABLE III

Anti-streptolysin $O(A S O)$, anti-DNAase $B$ and anti-M-associated protein (anti-MAP) titres of sera obtained from subjects in two outbreaks of upper respiratory tract infection

\begin{tabular}{|c|c|c|c|c|c|}
\hline \multirow{2}{*}{$\begin{array}{c}\text { Outbreak } \\
\text { number }\end{array}$} & \multirow{2}{*}{ Serum category } & \multirow{2}{*}{$\begin{array}{c}\text { Number of } \\
\text { sera } \\
\text { examined }\end{array}$} & \multicolumn{3}{|c|}{$\underset{\text { for }}{\text { Antibody titre }(50 \% \text { value } \dagger)}$} \\
\hline & & & ÁSO & anti-DNAase B & anti-MAF \\
\hline 1 & $\left\{\begin{array}{l}\text { (a) all with evidence of } \\
\text { recent streptococcal } \\
\text { infection* } \\
\text { (b) all with type } 5 \text { antibody } \\
\text { (c) with type } 5 \text { antibody and } \\
\text { evidence of recent } \\
\text { infection } \\
\text { (d) with evidence of recent } \\
\text { infection but no } \\
\text { type-specific antibody } \\
\text { to prevalent serotypes } \\
\text { (e) no evidence of recent } \\
\text { infection and no type- } \\
\text { specific antibody }\end{array}\right.$ & $\begin{array}{l}92 \\
36 \\
\\
32\end{array}$ & $\begin{array}{l}195 \\
260 \\
300\end{array}$ & $\begin{array}{r}365 \\
<50\end{array}$ & $\begin{array}{l}30 \\
54 \\
\\
62\end{array}$ \\
\hline 4 & $\begin{array}{l}\text { (a) see (a) above } \\
\text { (b) all sera with type } 22 \\
\text { antibody } \\
\text { (c) with type } 22 \text { antibody } \\
\text { and evidence of recent } \\
\text { infection } \\
(d) \text { see }(d) \text { above } \\
(e) \text { see }(e) \text { above }\end{array}$ & $\begin{array}{r}61 \\
15 \\
12 \\
17 \\
6\end{array}$ & $\begin{array}{l}312 \\
267 \\
\\
320 \\
300 \\
140\end{array}$ & $\begin{array}{l}500 \\
350\end{array}$ & $\begin{array}{r}9 \\
7 \\
\\
10 \\
3 \\
5\end{array}$ \\
\hline
\end{tabular}

* Evidence of recent streptococcal infection = elevated ASO or anti-DNAase B titre, or both.

$\dagger$ Obtained from cumulative percentage plots.

sera included in our calculations came from patients who had been infected with the relevant type of streptococcus. This caused difficulties with the data from outbreaks such as no. 1 and no. 4 (see table $I$ ) in which more than one serotype was involved. We first made a general comparison of antibody titres in outbreaks 1 and 4 by including all sera with elevated ASO and anti-DNAase B titres or both (see table III). The ASO and anti-DNAase B titres were somewhat higher in outbreak no. 4 than in outbreak no. 1, but in spite of this the $50 \%$ value for the anti-MAP titres was only 9 in outbreak no. 4 compared with 30 in 
outbreak no. 1. Moreover, in outbreak no. 4 about $70 \%$ of patients with evidence of recent streptococcal infection had anti-MAP titres of less than 20 compared with only $15 \%$ of the patients in outbreak no. 1 . More stringent selection of the sera (see table III) magnified this trend; for example, patients with type-5 antibody had high titres of anti-MAP much more often than did patients with type-specific antibody to type 22, irrespective of whether the groups were selected to contain sera with evidence of recent streptococcal infection or not. Fig. 1 shows that the plots of cumulative percentage values for the ASO

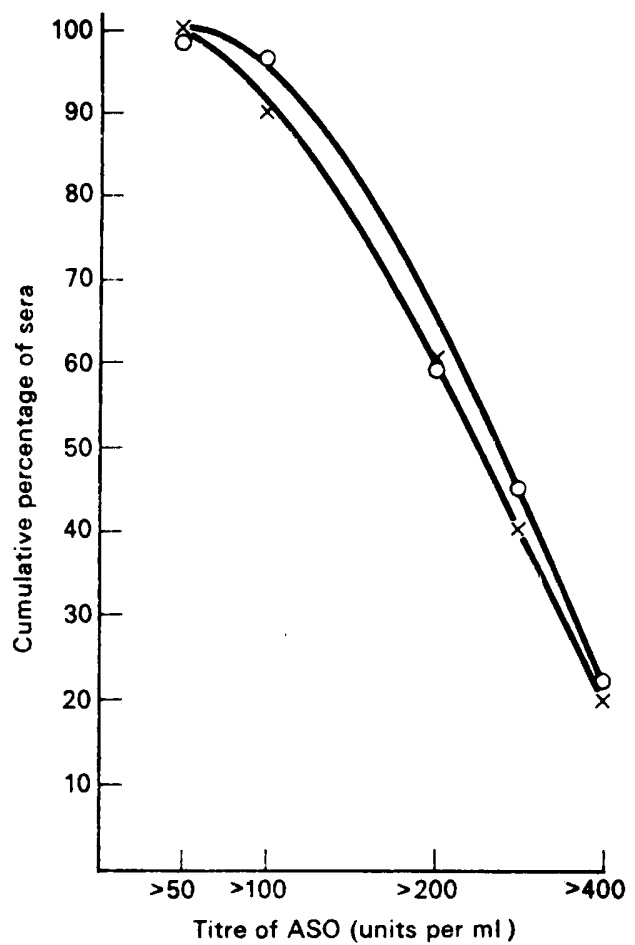

FIG. 1.-Plots of the cumulative percentage values for the ASO titres of the sera of 15 patients with type-22M antibody (X), and 36 patients with type-5M antibody (O).

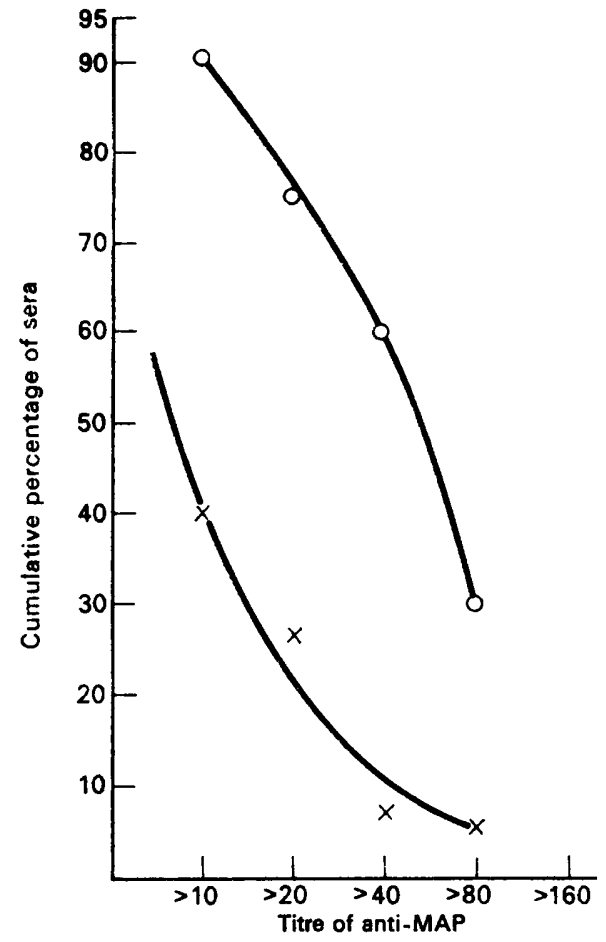

FIG. 2.-Plots of the cumulative percentage values for the anti-MAP titres of the sera of 15 patients with type-22M antibody (X), and 36 patients with type-5M antibody (O).

titres of 36 sera from outbreak no. 1 that contained antibody to type 5 and of 15 sera from outbreak no. 4 that contained antibody to type 22 , were very similar. On the other hand, the corresponding plots for anti-MAP titres showed a large difference (see fig. 2).

Among the sera with no type-specific antibody to any of the types prevalent in the outbreaks, the anti-MAP titres ranged from low to moderate in groups of sera from subjects with or without evidence of recent streptococcal infection. Anti-MAP titres in sera from subjects without evidence of recent infection and without type-specific antibody were higher in outbreak no. $1(50 \%$ value $=13)$ than in outbreak no. $4(50 \%$ value $=5$, ) but both values were of the same order as those observed for samples of normal populations (see table $\mathrm{V}$ ). 
Sufficient sera were available to make comparisons of $50 \%$ values of the titres of ASO, anti-DNAase B and anti-MAP in 11 of the 12 incidents. Table IV gives these values for the incidents comprising outbreaks 1-6 (except incident $1 C$ ); these data were obtained from sera in which the relevant typespecific antibody was present. Only four eligible sera from incident $1 \mathrm{C}$ were available. Sera could not be selected in this way in incidents 7,8 and 9 because the type-specific antibody response was too poor (see table II). However, all the patients involved in these incidents had had positive isolations of the relevant type of streptococcus from the skin and had anti-DNAase titres that were indicative of recent infection. Therefore, it was considered justified to include all of the sera.

\section{TABLE IV}

Anti-streptolysin $O(A S O)$, anti-DNAase $B$ and anti-M-associated protein (anti-MAP) responses of subjects in 11 incidents of streptococcal infection caused by various serotypes

\begin{tabular}{|c|c|c|c|c|c|c|c|}
\hline \multirow{2}{*}{$\begin{array}{l}\text { Incident } \\
\text { number }\end{array}$} & \multirow{2}{*}{$\begin{array}{l}\text { Infecting } \\
\text { M-type }\end{array}$} & \multirow{2}{*}{$\begin{array}{l}\text { Site of } \\
\text { infection }\end{array}$} & \multirow{2}{*}{$\begin{array}{c}\text { Serum } \\
\text { opacity } \\
\text { reaction } \\
\text { of the } \\
\text { infecting type }\end{array}$} & \multirow{2}{*}{$\begin{array}{l}\text { Number } \\
\text { of sera } \\
\text { examined* }\end{array}$} & \multicolumn{3}{|c|}{ Titre ( $50 \%$ value $\dagger$ ) for } \\
\hline & & & & & ASO & anti-DNAase B & anti-MAP \\
\hline $\begin{array}{l}6 \\
1 \mathrm{~A} \\
3 \\
1 \mathrm{~B} \\
8 \\
5 \\
2 \\
4 \mathrm{~A} \\
4 \mathrm{~B} \\
7 \\
9\end{array}$ & $\begin{array}{c}5 \\
5 \\
5 \\
18 \\
57 \\
18 \\
6 \\
12 \\
22 \\
\text { “Alabama 2" } \\
60\end{array}$ & $\begin{array}{l}\text { Throat } \\
\text { Throat } \\
\text { Throat } \\
\text { Throat } \\
\text { Skin } \\
\text { Throat } \\
\text { Throat } \\
\text { Throat } \\
\text { Throat } \\
\text { Skin } \\
\text { Skin }\end{array}$ & $\begin{array}{l}\text { Negative } \\
\text { Negative } \\
\text { Negative } \\
\text { Negative } \\
\text { Negative } \\
\text { Negative } \\
\text { Negative } \\
\text { Negative } \\
\text { Positive } \\
\text { Positive } \\
\text { Positive }\end{array}$ & $\begin{array}{r}11 \\
36 \\
7 \\
18 \\
10 \\
6 \\
19 \\
42 \\
15 \\
12 \\
10\end{array}$ & $\begin{array}{l}260 \\
260 \\
280 \\
175 \\
185 \\
340 \\
200 \\
287 \\
267 \\
165 \\
120\end{array}$ & $\begin{array}{r}720 \\
300 \\
\text { ND } \\
170 \\
2800 \\
365 \\
440 \\
500 \\
350 \\
1800 \\
4500\end{array}$ & $\begin{array}{c}73 \\
54 \\
45 \\
37 \\
36 \\
35 \\
27 \\
12 \\
7 \\
12 \cdot 5 \\
12 \cdot 5\end{array}$ \\
\hline
\end{tabular}

* In incidents $1 \mathrm{~A}, 1 \mathrm{~B}, 2,3,4 \mathrm{~A}, 4 \mathrm{~B}, 5$ and 6 only sera with type-specific antibody to the relevant type were included in the calculations; in incidents 7,8 , and 9 all the sera had raised anti-DNAase $\mathrm{B}$ titres and were from bacteriologically diagnosed infections.

$\dagger$ Obtained from cumulative percentage plots. $\mathrm{ND}=$ Not done.

There was some variation between the $50 \%$ values of the ASO titres and the anti-DNAaseB titres for the different serotypes that caused the outbreaks of respiratory tract infection, but in general these did not differ by more than a factor of 2. Deviations from this general pattern included the expected low ASO values and high DNAase B values for the cases of impetigo (incidents 7, 8 and 9) and the low value for both antibodies associated with a high anti-MAP value for one of the two type-18 incidents.

The $50 \%$ values for the anti-MAP titres, on the other hand, covered a wide range extending from 7 for type 22 (incident 4B) to over 70 for type 5 (incident 6). All three of the incidents associated with type 5 had values of 45 or greater and the two type-18 incidents had values of 35-40. The incidents in which cases of rheumatic fever were reported-nos. 1A, 5 and 6 -had values of 54,35 and 70 respectively. Low values $(7-12 \cdot 5)$ were obtained from all three incidents of 
infection due to OF-positive serotypes, but type 12 also gave rise to a similarly low value.

Comparison of antibody titres in rheumatic fever and acute glomerulonephritis

The ASO, anti-DNAase B and anti-MAP titres were determined for the groups of sera described in Materials and methods. These comprised in all 78

TABLE V

Antibody titres of sera from patients with rheumatic fever or acute glomerulonephritis and from normal subjects

\begin{tabular}{|c|c|c|c|c|c|c|}
\hline \multirow{2}{*}{ Disease } & \multirow{2}{*}{$\begin{array}{l}\text { Site of primary } \\
\text { streptococcal } \\
\text { infection }\end{array}$} & \multirow[b]{2}{*}{ Country } & \multirow{2}{*}{$\begin{array}{l}\text { Number } \\
\text { of sera }\end{array}$} & \multicolumn{3}{|c|}{ Titre $(50 \%$ value* $)$ for } \\
\hline & & & & ASO & Anti-DNAase B & Anti-MAP \\
\hline $\begin{array}{l}\text { Rheumatic } \\
\text { fever }\end{array}$ & $\begin{array}{l}\text { Throat } \\
\text { Throat } \\
\text { Not known }\end{array}$ & $\begin{array}{l}\text { U.K. } \\
\text { Egypt } \\
\text { Trinidad }\end{array}$ & $\begin{array}{l}23 \\
47 \\
18\end{array}$ & $\begin{array}{l}600 \\
300 \\
260\end{array}$ & $\begin{array}{l}1400 \\
1200 \\
1750\end{array}$ & $\begin{array}{r}105 \\
90 \\
100\end{array}$ \\
\hline \multirow[b]{2}{*}{$\begin{array}{l}\text { Acute } \\
\text { glomerulo- } \\
\text { nephritis }\end{array}$} & Throat & $\begin{array}{l}\text { U.K. } \\
\text { U.S.A. }\end{array}$ & $\left.\begin{array}{r}13 \\
5\end{array}\right\}$ & 320 & $400 \dagger$ & 19 \\
\hline & Skin & $\begin{array}{l}\text { U.K.K. } \\
\text { U.S.A. } \\
\text { Trinidad } \\
\text { Nigeria } \\
\text { Trinidad }\end{array}$ & $\left.\begin{array}{r}5 \\
4 \\
7 \\
13 \\
20\end{array}\right\}$ & 165 & 2000 & 18 \\
\hline $\begin{array}{l}\text { None } \\
\text { (Adults) }\end{array}$ & $\cdots$ & U.K. & 122 & 50 & 65 & 8 \\
\hline $\begin{array}{l}\text { None } \\
\text { (Schoolchildren) }\end{array}$ & $\cdots$ & Egypt & 50 & 100 & 375 & 15 \\
\hline $\begin{array}{l}\text { None } \\
\text { (Schoolchildren) }\end{array}$ & $\cdots$ & Nigeria & 12 & 100 & 400 & 10 \\
\hline
\end{tabular}

* Calculated from cumulative percentage plots.

$\dagger$ From nine cases only.

sera from patients with rheumatic fever and 67 from patients with acute nephritis. Although data from paired or serial bleedings were available from some patients, we have confined our comparisons to single bleedings taken up to 4 weeks after the onset of either disease. Table $\mathrm{V}$ shows the $50 \%$ values calculated from cumulative percentage curves for the various groups of sera. Data calculated from groups of presumed normal persons are included in the table for comparison. The $50 \%$ values for the ASO titres of patients with rheumatic fever or acute nephritis following throat infection were high (300-600) compared with the corresponding values for nephritis following skin infection (130-165). The site of primary infection was unknown for the 18 cases of rheumatic fever from Trinidad (see Potter et al., 1972) and the $50 \%$ value for the ASO titres of this group, although somewhat lower (260) than that for the cases of rheumatic fever of known respiratory origin (300-600), was twice the corresponding value of 130 for nephritis following skin infection in Trinidad. The $50 \%$ value for 
the ASO titres of normal British adults was 50 compared with a value of 100 for the presumed normal schoolchildren from Egypt and Nigeria, but in the absence of full information on the age distribution of the ASO titre in all countries it is difficult to judge the significance of a difference of this magnitude. The difference between the anti-DNAase B titres of the British and overseas normal sera was much more striking. A possible explanation of this is the higher prevalence of streptococcal infection, particularly of the skin, in young children in tropical climates. The age difference between our normal groups

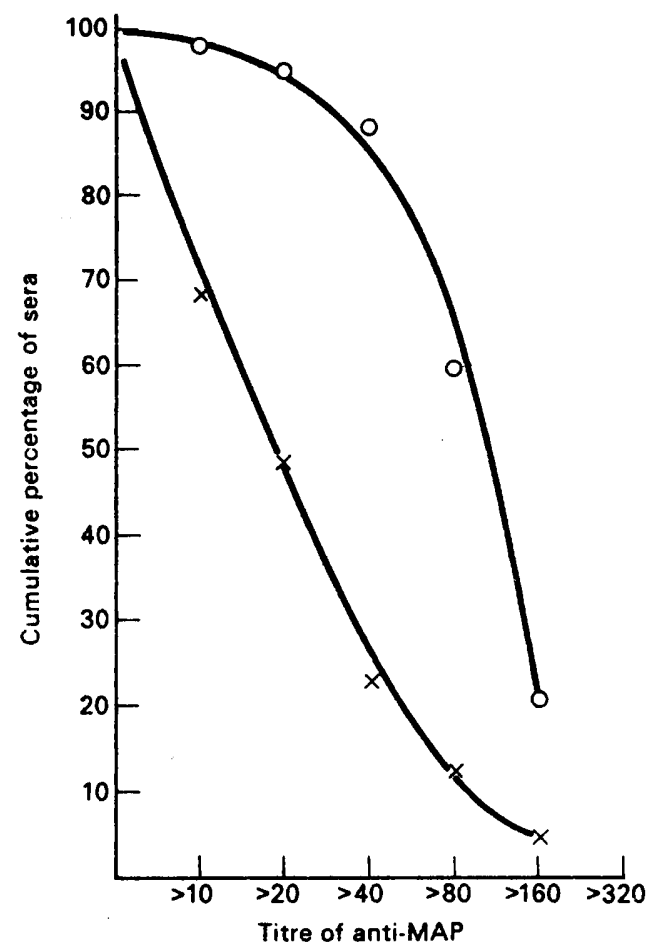

FrG. 3.-Plots of the cumulative percentage values for the anti-MAP titres of the sera of 78 patients with rheumatic fever $(\mathrm{O})$, and 67 patients with acute glomerulonephritis $(\mathrm{X})$.

seems unlikely to be a major contributing factor (see Klein, Baker and Jones, 1971).

As expected, the anti-DNAase B titres were extremely high in nephritis after skin infection (Anthony et al., 1967; Dillon and Reeves, 1969) but considerably lower in the few cases of nephritis after throat infection for which data were available (see footnote to table $\mathrm{V}$ ). The $50 \%$ values of the anti-DNAase B titres for subjects with rheumatic fever in the UK, Egypt and Trinidad were all moderately high and rather similar (1400,1200 and 1750 respectively), although the " background level" of this antibody among normal persons was much higher in Egypt (and also possibly in Trinidad) than in the UK.

The $50 \%$ value for the anti-MAP titres of 122 normal British adults was 8 compared with values of 10 and 15 for the Nigerian and Egyptian children 
respectively. There were striking and consistent differences in anti-MAP titres between the groups of sera from rheumatic fever patients and from patients with acute nephritis, regardless of the country of origin or the site of the primary infection; $50 \%$ values of between 90 and 105 were obtained for the three groups of rheumatic fever patients, compared with values of between 19 and 25 for the groups of patients suffering from acute glomerulonephritis. Fig. 3 illustrates graphically the difference between the cumulative percentage curves for the anti-MAP titres of sera from patients with nephritis and with acute rheumatic fever.

\section{DisCUSSION}

Prospective studies of streptococcal antibody response are almost impossible to perform; if infection is diagnosed early, treatment must be given, and the antibody response may be greatly diminished (Denny, Perry and Wannamaker, 1957). To avoid this difficulty we investigated retrospectively outbreaks of streptococcal infection in which action was delayed, although we were aware that this would make it difficult to decide who had been infected. Where matched positive swabs and serum samples were available from the same patients we were able to calculate the percentage type-specific antibody response directly by our method B. This was not always possible when we had only random samples of group-A streptococci that had been isolated rather late in the outbreak, followed some weeks later by similarly random samples of sera from the community. Even where a certain amount of " matching" was possible, method $B$ resulted in wastage of information. We therefore had to adopt the rather more unorthodox method of comparing the type-specific antibody response in patients who 4-6 weeks after the outbreak had serological evidence of recent streptococcal infection. The results obtained by the two methods of analysis agreed reasonably well and indicated the same wide difference in type-specific antibody response to particular serotypes.

The poor type-specific antibody response to the "difficult" M-types in rabbits is associated with the production of an OF by these types (Gooder, 1961 ; Top and Wannamaker, 1968; Widdowson et al., 1970). There are also striking differences between the OF-positive and OF-negative serotypes in the molecular size distribution and heterogeneity of their $\mathbf{M}$ proteins, both in acid extracts (Widdowson et al., 1971b) and in culture supernates (Pinney, 1974). Our results show that this difference in antigenicity also affects the type-specific antibody response in man to throat infections with OF-positive and OFnegative serotypes. The sera of about $70 \%$ of patients infected with OFpositive serotypes showed no detectable bactericidal effect against the infecting strain, whereas the sera of the majority of patients suffering from throat infections with OF-negative serotypes were strongly positive in the indirect bactericidal test. The type-specific antibody response was poor and infrequent $(0-33 \%)$ in all three incidents of streptococcal pyoderma, irrespective of whether the infecting serotype was OF-positive (type 60 and "Alabama 2") or OF-negative (type 57). Potter et al. (1971) found that the type-specific antibody response to skin infection with the OF-positive serotype M49 was also 
poor, but that the response to infection with the OF-negative serotype M55 was more frequent and vigorous. Obviously more information is needed, but it is possible that the type-specific antibody response to some infections may be more transient than in others (Šrámek, 1974).

The $50 \%$ values for the ASO and anti-DNAase B responses to infection with different serotypes did not vary greatly, except that serotypes responsible for impetigo gave rise to higher anti-DNAase B titres and lower ASO titres than did serotypes associated with throat infection. Whether this is a character of the infecting strain or a consequence of the site of infection is still uncertain (Wannamaker, 1970). On the other hand, anti-MAP titres varied widely for different serotypes and again there was a strong impression that the OF-positive serotypes were the least antigenic. Anti-MAP titres were very low (50\% values: $7-12.5$ ) after infection with the OF-positive serotypes "Alabama 2", 22 or 60 . Among the OF-negative serotypes, however, there was a wider variation in anti-MAP values. Some M-types, such as 5 and 18, gave consistently high values whilst others, e.g., type 12, gave results of the same order as the OF-positive serotypes.

Acute glomerulonephritis may follow infection by any one of a small number of serotypes, some of which cause throat infection and others skin infection (see Wannamaker, 1970), but differences in the "rheumatogenicity" of serotypes of group-A streptococci have not been clearly demonstrated, and there is evidence that many group-A serotypes that cause tonsillitis can give rise to rheumatic fever (Rammelkamp, Denny and Wannamaker, 1952). However, rheumatic fever and nephritis rarely if ever occur in the same patient after a single streptococcal infection (Cohen et al., 1971) or in the same outbreak of streptococcal disease. Although acute nephritis is frequently associated with pyoderma, it is generally believed that rheumatic fever is not (Wannamaker, 1970). This suggests a divergence of the serotypes able to cause nephritis from those capable of causing rheumatic fever and it has been suggested that the properties of "rheumatogenicity" and " nephritogenicity" may be mutually exclusive (see Stollerman, 1969).

A grossly raised anti-MAP titre is found in nearly all cases of rheumatic fever; the titre exceeded 60 in $100 \%$ of the British, $70 \%$ of the Egyptian and $78 \%$ of the Trinidadian cases shown in table V. Certain serotypes of group-A streptococci give rise to high titres of the antibody after uncomplicated infection of the upper respiratory tract. In three of the outbreaks of throat infection that we studied, high anti-MAP titres were common and cases of rheumatic fever occurred; in incidents of infection due to other serotypes, high titres were very infrequent and rheumatic fever was not seen. Although the number of outbreaks in the present study is small, the findings are consistent with the view that "rheumatogenic" strains of group-A streptococci are among those that give rise to high titres of anti-MAP. Such strains are to be found among the OFnegative serotypes, but these appear to vary greatly in their ability to stimulate anti-MAP production. In general the type-specific antibody response of OFnegative serotypes is also good, but it is not obviously better with strains that promote large amounts than with those that promote smaller amounts of antiMAP. 


\section{SUMMARY}

The influence of the infecting serotype on streptococcal antibody response in man was investigated in a series of twelve incidents of streptococcal infection due to nine different M-types. The percentage of patients who developed typespecific $M$ antibody after throat infection with opacity-factor-negative $\mathbf{M - t y p e s}$ varied between 64 and $100 \%$ and was in general three times greater than the percentage who developed this antibody to opacity-factor-positive $\mathbf{M}$ types. The type-specific antibody response was poor after skin infection with both opacity-factor-positive and opacity-factor-negative serotypes and varied between 0 and $33 \%$.

Antistreptolysin $\mathrm{O}$ and anti-deoxyribonuclease $\mathrm{B}$ titres were on the whole similar in the different outbreaks, except that anti-streptolysin $\mathrm{O}$ titres were low and anti-deoxyribonuclease B titres were high in patients with skin infection.

The antibody response to M-associated protein varied widely between outbreaks. In incidents due to opacity-factor-positive serotypes, the titres were generally low, but opacity-factor-negative serotypes showed great variation in their ability to cause production of the antibody. In outbreaks of tonsillitis in which some of the patients later suffered from rheumatic fever, many persons formed large amounts of the antibody in response to an uncomplicated infection. Because high titres of antibody against M-associated protein are almost invariable in rheumatic fever it seems possible that the "rheumatogenic" strains of group-A streptococci are to be found among the opacity-factornegative serotypes.

Our thanks are due to Dr Wafaya El Razaz, Dr B. F. Anthony, Dr T. Poon-King, Dr Elizabeth V. Potter, Dr I. Mohammed, Dr R. Cox, Dr H. C. Dillon, Dr H. Whittle, Dr A. L. Furniss, Dr W. L. Hooper, Dr C. Newrick and Dr D. Parkin for sera and strains used in this investigation.

\section{REFERENCES}

Anthony, B. F., Perlman, L. V. and Wannamaker, L. W. 1967. Skin infections and acute nephritis in American Indian children. Pediatrics, Springfield, 39, 263.

Anthony, B. F., Yamuchi, T., Penso, J. S., Kamei, I. And Chapman, S. S. 1974. Classroom outbreak of scarlet fever and acute nephritis related to type 2 (M-2, T-2) group A streptococcus. J. infect. Dis., 129, 336.

Cohen, S., Salmon, M., Grishman, E., Gribetz, D. and Churg, J. 1971. The kidney in acute rheumatic fever. Archs intern. Med., 127, 245.

Denny, F. W., Perry, W. D. and Wannamaker, L. W. 1957. Type-specific streptococcal antibody. J. clin. Invest., 36, 1092.

Dillon, H. C. AND Rreves, M. S. 1969. Streptococcal antibody titres in skin infection and AGN. Pediat. Res., 3, 362.

Dillon, H. C., Reeves, M. S. AND Maxted, W. R. 1968. Acute glomerulonephritis following skin infection due to streptococci of M-type 2. Lancet, 1, 543.

GOODER, H. 1961. Association of a serum opacity reaction with serological type in Streptococcus pyogenes. J. gen. Microbiol., 25, 347.

GoODER, H. AND Williams, R. E. O. 1961. Titration of antistreptolysin O. Association of Clinical Pathologists Broadsheet no. 34 (New Series), London.

GRIFFITH, F. 1934. The serological classification of Streptococcus pyogenes. J. Hyg., Camb., 34,542 . 
Kaplan, E. L., Top, F. H., Dudding, B. A. And Wannamaker, L. W. 1971. Diagnosis of streptococcal pharyngitis. Differentiation of active infection from the carrier state in the symptomatic child. J. infect. Dis., 123, 490.

KLEIN, G. C., BAKER, C. N. AND JoNES, W. L. 1971. "Upper limits of normal" antistreptolysin $\mathrm{O}$ and antideoxyribonuclease B titres. Appl. Microbiol., 21, 999.

MAXTED, W. R. AND WIDDOwson, J. P. 1972. The protein antigens of group A streptococci. In Streptococci and streptococcal diseases, edited by L. W. Wannamaker and J. M. Matsen, New York and London, p. 251.

MaXted, W. R., WidDowson, J. P. AND Fraser, C. A. M. 1973. Antibody to streptococcal opacity factor in human sera. J. Hyg., Camb., 71, 35.

Nelson, J., Ayoub, E. M. AND Wannamaker, L. W. 1968. Streptococcal antideoxyribonuclease B: microtechnique determination. J. Lab. clin. Med., 71, 867.

Potter, E. V., Ortiz, J. S., Sharratt, A. R., Burt, E. G., Bray, J. P., Finklea, J.F., Poon-KIng, T. AND EaRLe, D. P. 1971. Changing types of nephritogenic streptococci in Trinidad. J. clin. Invest., 50, 1197.

Potter, E. V., Svartman, M., Burt, E. G., Finklea, J. F., Poon-King, T. and Earle, D. P. 1972. Relationship of acute rheumatic fever to acute glomerulonephritis in Trinidad. J. infect. Dis., 125, 619.

Pinney, A. M. 1974. Some type-associated characteristics of group A streptococci. In Streptococcal disease and the community, Proceedings of the Fifth International Symposium on Streptococcus pyogenes, Amsterdam, Aug. 27-Sept. 1, 1972, edited by M. J. Haverkorn, Amsterdam and New York, p. 56.

Rammelkamp, C. H., Denny, F. W. AND Wannamaker, L. W. 1952. Studies on the epidemiology of rheumatic fever in the Armed services. In Rheumatic fever, edited by L. Thomas, Minneapolis, p. 72.

Siegel, A. C., Johnson, E. E. AND Stollerman, G. H. 1961. Controlled studies of streptococcal pharyngitis in a pediatric population. 2. Behaviour of the type-specific immune response. New Engl. J. Med., 265, 566.

ŠRÁmEK, J. 1974. Streptococcal anti-M antibodies in sporadic acute glomerulonephritis. In Streptococcal disease and the community, Proceedings of the Fifth International Symposium on Streptococcus pyogenes, Amsterdam, Aug. 27-Sept. 1, 1972, edited by M. J. Haverkorn, Amsterdam and New York, p. 301.

Stollerman, G. H. 1969. Nephritogenic and rheumatogenic group A streptococci. $J$. infect. Dis., 120, 258.

SWIFT, H. F., Wilson, A.T. ANd LANCEFIELd, R. C. 1943. Typing group A haemolytic streptococci by M-precipitin reactions in capillary pipettes. J. exp. Med., 78, 127.

TOP, F. H. AND WANNAMAKER, L. W. 1968. The serum opacity reaction of Streptococcus pyogenes: frequency of production of streptococcal lipoproteinase by strains of different serological types and the relationship to M protein production. J. Hyg., Camb., 66, 49.

WANNAMAKER, L. W. 1970. Differences between streptococcal infections of the throat and of the skin. New Engl. J. Med., 282, 23, 78.

Whittle, H. C., Abdullahi, M. T., Fakunle, F., Parry, E. H. O. and Rajkovic, A. D. 1973. Scabies, pyoderma and nephritis in Zaria, Nigeria, a clinical and epidemiological study. Trans. R. Soc. trop. Med. Hyg., 67, 349.

Widdowson, J. P., Maxted, W. R. AND Grant, D. L. 1970. The production of opacity in serum by group A streptococci and its relationship with the presence of M-antigen. J. gen. Microbiol., 61, 343.

Wmdowson, J. P., MaXted, W. R. ANd Pinney, A. M. 1971a. An M-associated protein antigen (MAP) of group A streptococci. J. Hyg., Camb., 69, 553.

Widdowson, J. P., Maxted, W. R., Grant, D. L. AND Pinney, A. M. 1971b. The relationship between M-antigen and opacity factor in group A streptococci. J. gen. Microbiol., $65,79$.

Widdowson, J. P., MaXted, W. R., Newrick, C. AND Parkin, D. 1974. An outbreak of streptococcal sore throat and rheumatic fever in a Royal Air Force training camp; significance of serum antibody to M-associated protein. J. Hyg., Camb., 72, 1. 